This is an electronic reprint of the original article. This reprint may differ from the original in pagination and typographic detail.

Author(s): Rantala, Salla; Kontinen, Tiina; Korhonen-Kurki, Kaisa; Mustalahti, Irmeli

Title: $\quad$ Equity in REDD+: Varying logics in Tanzania

Year: $\quad 2015$

Version:

Please cite the original version:

Rantala, S., Kontinen, T., Korhonen-Kurki, K., \& Mustalahti, I. (2015). Equity in REDD+:

Varying logics in Tanzania. Environmental Policy and Governance, 25(3), 201-212. https://doi.org/10.1002/eet.1669

All material supplied via JYX is protected by copyright and other intellectual property rights, and duplication or sale of all or part of any of the repository collections is not permitted, except that material may be duplicated by you for your research use or educational purposes in electronic or print form. You must obtain permission for any other use. Electronic or print copies may not be offered, whether for sale or otherwise to anyone who is not an authorised user. 


\title{
Equity in REDD+: varying logics in Tanzania
}

\begin{abstract}
Equity is frequently cited as one of the key design aspects of environmental governance regimes. In the context of Reduced Emissions from Deforestation and Forest Degradation (REDD+), a forest-based climate change mitigation instrument, the manner in which 'equity' is understood will be of critical importance for the impacts and acceptance of REDD+ policies and initiatives. Whereas the concept has been extensively studied in the academic literature, references to equity in REDD+ policy debates and documents are often vague, leaving room for various interpretations and modes of implementation. In our case study of the Tanzanian national REDD+ policy domain, we provide a conceptual framework based on an institutional logics approach for analysing the various underlying rationales in the 'equity in REDD+' debate. We apply it to demonstrate how the involved policy actors draw from heterogeneous equity logics in their support for and opposition to different governance models, highlighting the importance of precise contextualization and operationalization of broad international principles in national REDD+ initiatives.
\end{abstract}

Keywords: REDD+, equity, institutional logics, policy, Tanzania 


\section{Introduction}

Climate change poses enormous governance challenges and has profound social implications for people. One of the key challenges currently faced by policy makers relates to understanding variation among the short- and long-term priorities of different groups of stakeholders, and balancing them for legitimate and effective climate change policies. In policy and academic debates on Reducing Emissions from Deforestation and Forest Degradation (REDD+), a climate change mitigation mechanism based on incentives and compensation for the maintenance and enhancement of carbon stocks in tropical forests and trees, concerns over social justice are accentuated (Peskett et al., 2011; McDermott et al., 2012). It is argued that while REDD+ might have potential to bring benefits to local communities in developing countries in the form of rewards for forest conservation and sustainable forest management, REDD+ also carries the risk of livelihood losses and marginalization of forest-dependent people due to recentralization of forest governance and appropriation of benefits by states and other more powerful actors (Griffiths, 2008; Cotula and Mayers, 2009; Agrawal et al. 2010; Phelps et al., 2010; Sandbrook et al., 2010). Framing the REDD+ debate around winners and losers the latter invariably identified as forest-dependent communities and indigenous peoples - is central to the critique towards REDD+ articulated by a number of environmental and social organizations (Griffiths, 2008; Di Gregorio et al., 2013). At the same time, there is a growing consensus that effective and equitable participation by a wide range of stakeholders, including local forest users, is needed for REDD+ to succeed (cf. UNFCCC, 2011).

Consequently, 'equity' is frequently cited as one of the key aspects for the design of national and sub-national REDD+ interventions (Angelsen, 2008; Angelsen et al., 2009; Peskett et al., 2011). Yet, the term is generally left undefined (McDermott et al., 2012) or mentioned in passing among the other "three E:s", effectiveness and efficiency (Angelsen 2008, Angelsen et al. 2009). In the 3E framework, equity is seen to concern the fair distribution of REDD+ benefits within and among countries (Angelsen and Wertz-Kanounnikoff, 2008). A key concept in the literature on environmental justice, distributive equity is concerned with the "distribution of 'goods' and 'bads' in society and 
the principles by which these benefits and burdens are, or should be, distributed" (McDermott et al., 2012, p. 3). The focus in the Northern hemisphere has tended to be on the unequal distribution of environmental burden, while in the South, on that of benefits (Schroeder et al., 2008). While REDD+ implementation is still incipient, equity in REDD+ is most frequently discussed in relation to potential benefit-sharing mechanisms between governments and forest custodians (Peskett et al., 2011; Balderas Torres and Skutsch, 2012; Pham et al., 2013; Skutsch et al., 2013; Luttrell et al. 2013).

Partly as a response to critique of too narrow a definition of equity in terms of distribution of burden or benefits (Schroeder et al., 2008; McDermott et al., 2012), attention has been drawn to the procedural equity of planning and decision-making processes. Matters of choice, access, recognition, participation, representation and distribution of power shape the fairness of political, legal, market, and other processes that allocate resources and resolve disputes (Paavola, 2007; Schroeder et al., 2008; McDermott et al., 2012; Wutich et al., 2013). Procedural and distributive equity are thus intrinsically linked (Paavola, 2007; Schroeder et al., 2008). McDermott et al. (2012) discuss the effect of previous distributive and procedural inequities on current Payments for Environmental Services (PES) and REDD+ interventions as contextual equity; the political, economic and social conditions present at the start of an intervention that shape access to it (cf. Brown and Corbera, 2003). It has been warned that strong social safeguards are needed so that REDD+ will not reproduce or further strenghten the existing regressive conditions, the "uneven playing field", present in many countries preparing REDD+ interventions (Ribot and Larson, 2012; Mustalahti and Rakotonarivo, 2014).

In climate change and REDD+ documents and debates, equity issues, principles and criteria are often presented in a normative tone and as impetus for desired practice, i.e. ideal descriptions of how things should be (Heyward, 2007; Angelsen et al., 2009; Mustalahti et. al., 2012). But what is considered equitable by whom? Varying conceptions of equity are based on particular actors' perspectives and circumstances instead of universal, shared meanings, and equity principles are used in accordance to 
users' interests (Heyward, 2007). This has important implications for the design of 'optimal' REDD+ strategies and initiatives. As noted by Wiegandt (2001, p. 148), "there is no rational nor scientific basis on which to choose among different conceptions of ethics". Lack of clarity on which dimensions of equity should be targeted further complicates the operationalization of the concept in REDD+ planning, decision making and implementation (McDermott et al., 2012). Various conceptions of equity are thus likely to come into conflict in the national and sub-national REDD+ processes in which distinct actors, often dissimilar in their interests and influence, participate.

This paper explores the various rationalities and logics regarding equity employed by organizational actors participating in the development of a national REDD+ strategy in Tanzania. Recognizing the conceptual as well as normative plurality in the equity in REDD+ debate, we turn to the theory of institutional logics (Friedland and Alford 1991; Thornton et al., 2012) which provides us with a useful conceptual angle to understand the logics and rationalities used to interpret and implement the global REDD+ debate at the level of organizational fields and individual organizations. Identifying the multiple rationalities and logics in the conceptualization of equity facilitates the understanding of the dynamics and outcomes of REDD+ policymaking and implementation. For instance, in our case study country, Tanzania, much of the debate surrounding the development of a national REDD+ strategy is focused on the design of a benefit-sharing mechanism between the government and local forest custodians. The government agencies spearheading the national REDD+ initiative argue that the best way to ensure equitable outcomes is state-controlled benefit distribution through a national trust fund, while civil society organizations, mainly domestic and international NGOs, critique the model for maintaining previous inequalities, namely state capture of forest benefits (Rantala and Di Gregorio, in press). We propose that central to this debate are the different, unspoken logics related to equity in the specific natural resource governance context in Tanzania, which are likely to continue to cause friction as REDD+ moves from the national debates to local level implementation.

Acknowledging previous, commendable efforts to conceptualize equity in PES and REDD+ interventions based on thorough reviews of relevant theoretical frameworks 
(e.g. McDermott et al., 2012; Di Gregorio et al., 2013), our contribution to this literature distinguishes itself by an inductive, data-driven approach. We depart from a working definition that draws from the theories of distributive and procedural equity, considering equity to be concerned with issues of negotiation power, participation in REDD+ decision making and implementation, and allocation of costs and benefits among the stakeholders and groups involved. Within that broad definition, we identify the kind of vocabularies and arguments that policy actors use in reference to equity in REDD+, and associate them with distinct institutional logics that guide the actors' preferences regarding REDD+ policy proposals. Our approach discloses the heterogeneity of logics related to equity within the nascent REDD+ policy field in Tanzania, suggesting that enhanced deliberation should be promoted in the operationalization of broad international principles in national policy processes instead of assuming that shared, taken-for-granted rationalities exist.

\section{Institutional Logics Perspective to Equity in REDD+}

The institutional logics approach is one of the most prominent approaches in the contemporary sociological organization theory (Meyer and Rowan, 1977; Friedland and Alford, 1991; Thornton and Ocasio, 1999; 2008; Greenwood et al. 2011; Thornton et al., 2012), though it has not yet been applied extensively in contexts spanning both the North and the South (but see Carter et al., 2011, for an application in the analysis of the global climate change negotiations). The approach suggests that institutional logics connect individual organizations, organizational fields revolving around certain products or services, and wider societal contexts. The societal institutional systems such as family, religion, state, market, profession, corporation and community function according to their own logics which facilitate the interpretation of social situations in different ways (Thornton et al., 2012; Friedland and Alford, 1991). For example, the logics of the state in modern societies revolve around bureaucratic rationality according to which the equity of citizens is guaranteed by a well-functioning governmental 'machine' (Weber, 1947). The logics of the family, in turn, have been attributed to the nuclear family characterized by close emotional relations (Friedland and Alford, 1991). The logics affect organizational fields and organizational behaviour by providing meanings and 
material practices which are reproduced and reinterpreted at the organizational level (Meyer and Rowan, 1977; DiMaggio and Powell, 1983; Thornton and Ocasio, 1999; p. 804). Fields and organizations also face institutional complexity (Greenwood et al., 2010; 2011; Yu, 2013; Kraatz and Block, 2008), and draw from multiple logics in their everyday functions. Thus, the identification of specific logics emerging in selected fields and organizations remains a question of empirical inquiry.

The institutional logics approach contributes to our analysis of the 'equity in REDD+' debate in Tanzania in three important ways. First, it provides grounds for organizational understanding of "what constitutes appropriate behavior" (Thorton, 2004, p. 70), and hence analysing the underlying institutional logics of 'appropriate equity' enables novel understanding of the rationalities behind REDD+ interventions. Second, we propose that REDD+ facilitates an emerging transnational field composed of organizational actors ranging from international negotiators to national and local governments, domestic and transnational civil society actors, local communities and forest users. The REDD+ field is partly a novel resource environment for these organizations in terms of material and conceptual resources, and partly overlaps with the existing fields of international development aid (cf. Tvedt 2006) and forest management and conservation, the requirements and resources of which enable and constrain REDD+ planning and implementation (e.g. Kanowski et al. 2011). Within the system, the concept of equity gains different theoretical, normative and practical meanings, and fits various forms of rationality. Third, we contend that the emerging organizational field of REDD+ is characterized by institutional complexity illustrated by inherent contradictions in the logics articulated (Greenwood et al., 2011). In a similar vein with, for example, the Canadian health care field characterized by competing logics of medical professionalism and business (Reay and Hinings, 2009), and Bolivian microfinance organizations struggling to balance the logics of development and banking (Battilana and Doraro, 2010), at least the logics of market and bureaucracy may be expected to apply to REDD+ as a transnational field, given the basic features of the mechanism that entail international financial transfers to national governments. Disclosing the mutual complementarities and/or inconsistencies between the underlying 
heterogeneous logics will help understand the diversity of policy models that are all proposed to lead to equity.

\section{Study Context and Methods}

\section{REDD+ in Tanzania}

Tanzania is one of the countries participating in the United Nations Programme on REDD+ (UN-REDD), and has received substantial support for 'REDD+ readiness' activities from the Norwegian government since 2008. These activities include the development of a national REDD+ strategy under the leadership of a national REDD+ Task Force, implementation of pilot REDD+ projects, as well as REDD+ research and capacity building. The final draft National REDD+ Strategy (URT, 2013) outlines two key structures for operationalizing REDD+ in Tanzania: a national trust fund for the administration and distribution of REDD+ rewards (payments), and a National Carbon Monitoring Centre which will provide technical services on measuring, reporting and verification of carbon stocks and REDD+ activities across the country. In March 2013, the government of Tanzania endorsed the National REDD+ Strategy and Action Plan (Daily News, 2013). The National REDD+ Strategy lists several general goals related to the development of equitable governance and institutional mechanisms for benefit sharing and capacity building (URT, 2013, p. 41, 42, 44, 45) but without defining what is meant by 'equitable' or detailing any explicit actions to operationalize it.

\section{Data Collection and Analysis}

Data on the equity logics of REDD+ actors were collected through in-depth, semistructured interviews with policy actors (organizational actors active in the REDD+ policy formulation and consultation processes in Tanzania) in March-June 2011 (Table 1). The interviews formed part of a larger study on the REDD+ policy process in Tanzania and did not solely target aspects of equity, which nevertheless came up extensively in the interviews. Equity was primarily discussed in relation to the development and content of the first draft national REDD+ strategy (URT, 2010) that 
had just been released for public comments. The approach to defining and identifying relevant policy actors was through a panel of seven experts (individuals well-acquainted with the REDD+ process in Tanzania and involved in it in different roles) who were asked to nominate organizational actors that considered themselves as part of the REDD+ policy domain and were recognized by other actors as such. In other words, our approach to defining policy actors was realist in emphasising reputational relevance (Laumann et al., 1992), resulting in the exclusion of, for instance, local communities and forest users that were not considered actors in the national policy formulation despite being stakeholders in REDD+. For each organization, a high-ranking official that could plausibly speak for the whole organization or the official that normally represented the organization in the national REDD+ strategy process was interviewed on the position and perspectives of their organization on REDD+. In total, 41 interviews were conducted.

The interviews were recorded and transcribed. Qualitative content analysis software was first used to extract relevant material, as longer strands of text, with reference to our working definition of equity. A manual thematic analysis of the resulting text extracts from 28 interviews was repeated three times by the first and the third author and based on input by the other authors, as the main patterns of different institutional logics on equity in REDD+ started to emerge and were sharpened. Since institutional logics are ideal types (Thornton et al., 2012), their identification requires a close inductive engagement with the vocabularies of practice and arguments uttered. Hence, we looked for repetitions of certain vocabulary and arguments, specific expressions, analogies and metaphors, as well as transitions and connectors in the interviewees' narratives to see how distinct arguments were linked (cf. Ryan and Bernard, 2003) in our effort to categorize the institutional logics of equity and their inner contradictions. The previous literature on institutional logics (Thornton et al., 2012) provided ideas for scoping the data, while we also intended to identify logics that might be specific for the Tanzanian context as well for REDD+ as a transnational organizational field. 
The distribution of different types of organizational actors among the final set of interviews included in the analysis is presented in Table 1. It is representative of the distribution of different types of actors in the REDD+ policy domain in Tanzania in 2011 as identified by the expert panel. The actual organization names are not disclosed because we guaranteed the interviewees full anonymity. It should be reiterated, however, that in line with the idea of analytical generalization typical of qualitative research (e.g. Mitchell, 2000), we have intended to describe the multiple institutional logics within the REDD+ policy domain in Tanzania, and more specifically, at the level of organizational actors as participants in this particular domain. Therefore, the emphasis is not on the frequency of utterances of distinct logics by certain types of actors, but on a 'thick description' (Geertz, 1973) of all the logics that could be identified.

\section{Findings: Institutional Logics for Equity in REDD+}

The arguments of the interviewed REDD+ actors were associated with several logics that could be related to three dimensions of the equity debate: first, why equity is a concern for REDD+ policies and initiatives; second, how equity in REDD+ interventions should be addressed; and third, what stands in the way of achieving equitable REDD+ processes and outcomes. Some of the logics resonated with the ideal types presented in the previous literature (e.g. market, bureaucracy, family), but certain arguments related to the importance of inclusive participation by a broad range of stakeholders could be considered specific to the current context of multilevel, multiactor governance not only in REDD+ but as a general recent trend in natural resource governance (Thompson et al., 2001; Forsyth, 2009). We identified six main categories of institutional logics, four of which were considered to possess inner tensions or distinctions. In resonance with the previous literature on institutional complexity, the interviewees typically presented arguments that could be related to several types of logics, that is, the main categories were not mutually exclusive. The results have been summarized in Table 2.

First, one of the most salient logics, in terms of the frequency of related arguments by all types of actors, was the market logic. It posits that REDD+ needs to 
provide sufficient financial incentives at the local community level so that the changes in behaviour and livelihood strategies required for a reduction in deforestation and forest degradation are achieved. This view stresses distributive equity in compensating for forgone income and opportunities; an aspect which, in the view of the interviewees, the previous approaches to forest conservation and community-based forest management in Tanzania had failed to address (e.g. Vyamana, 2009; Blomley et al., 2010; Rantala et al., 2012). Hopes were therefore placed on REDD+ funds to provide the needed incentives and compensation, as reflected in this comment by one of the interviewed government officials:

"The problem has been money and how do we make them [local communities] work. We give them incentives, so far not much. Then, when we heard about REDD+, we said $\mathrm{OK}$, if it is to enhance carbon stocks and reduce emissions, making people who are in the rural areas, the poor, not to cut trees but to keep them and maintain them, then if viable alternatives can come forward, then people can appreciate" (Government forestry official, April 26, 2011).

Second, the logic of rights, including both legal and moral rights to resources and to compensation for REDD+ related restrictions on resource access, constituted an important rationale to argue for equity in REDD+. These arguments were presented in relation to the Tanzanian context in which a distinction between legal and moral rightholders is relevant for the on-going discussion on defining REDD+ beneficiaries. Who is a legal right-holder may be subject to widely differing views in REDD+ implementation, due to varying interpretations of the national land and forest laws on tenure, not to mention the still-unresolved question of carbon rights. Parallel to the global REDD+ debate, civil society actors in Tanzania have campaigned for a more straightforward recognition of local communities' land and forest rights, which are intertwined in the decentralized legal framework. The government, as evident in the interviewees' comments as well as in the national policy documents on REDD+, continues to interpret the laws and regulations in such a way that the majority of land and forest still falls under its control (TFCG and MJUMITA, 2011; Rantala and Di Gregorio, in press). The moral rights argument sidesteps this quandary by stressing that all those whose 
livelihoods are affected by REDD+ should be taken into account, regardless of their legal position.

Third, our analysis revealed that there was a prevalent inner tension between the logics of an ideal type of modern bureaucracy (Weber, 1947) referring to efficient, transparent and impartial state machinery, and that of the existing bureaucracy in Tanzania as perceived and experienced especially by the civil society actors. They framed the problem as one of clientelistic governance in which the state captures all resources while failing both the equity and effectiveness aspects of REDD+. They did not favour the proposed national REDD+ trust fund because it was seen at risk of replicating their experience with previous natural resource management schemes in which governmental bureaucracy had swallowed most of the benefits, with very little left to be distributed at the local levels. As one of the NGO representatives justified the position of his organization, based on what they had observed in relation to benefit sharing from hunting concessions:

"The closest thing we see to that is $20 \%$ of the revenue is returned to districts, but even that doesn't then reach the communities where it has happened. So there's just no precedent in Tanzania. There's no history. There's a precedent of the exact opposite. So we don't think that a national reward system will work [...] If they're talking $90 \%$ of the income going to communities, then maybe that's fair. If they're talking about $20 \%$ which is like traditional here, right, with wildlife, then it's silly. It's not remotely equitable" (Domestic NGO technical advisor, April 5, 2011).

In contrast, notions of the logic of (an ideal type of) modern bureaucracy could be detected in the arguments of the governmental actors, who saw the state bureaucracy in a very different light; as an unbiased and efficient apparatus that guarantees the equity of REDD+ processes and outcomes. Although they, too, admitted that there was room for improvement in the performance of the national forest governance system, the interviewed governmental officials expressed a firm belief that the state could best oversee the administration of REDD+ accounting and reward payments, as long as principles such as good governance and transparency and accountability were actively promoted and followed. We saw this as related to the fourth identified logic of 
standards, which clearly connected the Tanzanian REDD+ equity debate to the international sphere. Within this logic, too, two contradictory sides could be identified: one taking the adoption of international standards and subsequent equity outcomes for granted, the other questioning their relevance in the current context. According to the sub-logic of established standards, equity and other good governance principles naturally flow from the international standards, agreements and partnerships, such as the UNFCCC and UN-REDD+, that Tanzania has agreed to follow. The flipside to this was pointed out by some NGO and international actors, referring to what we identified as the sub-category of 'buzzwords'. According to this logic, equity goals have been copied from the global discourse for a wider legitimacy of the national REDD+ strategy, but without clearly defining measures through which such goals might be achieved, so as to avoid accountability. As described by an NGO interviewee:

"It is very nicely written, these things, fairness, equity, gender balance, in the [policy] documents. But when it comes to actually doing, it is a different story [...] If you don't put up a very effective way of implementing to ensure that, life will go on as usual, yeah, business as usual" (Domestic NGO director, March 24, 2011).

Fifth, seen as both a justification for and a pathway to equitable REDD+ outcomes, the logic of participatory governance relates to the idea of REDD+ as a prime manifestation of multilevel, multi-actor governance spanning various jurisdictional scales and multiple sectors (Forsyth, 2009). The rationale that legitimate and effective policies require the equitable participation, direct or indirect, of as many stakeholders as possible, was salient in the arguments of all types of actors. Goals related to inclusive participation are frequently explicit in decentralization reforms taking place in many countries across the developing tropics (e.g. Larson et al., 2010), including Tanzania, where decentralized policies and legal frameworks for land, forest and local government were introduced in the late 1990s-early 2000s. Since then, a focus on the national Participatory Forest Management policy has dominated academic and policy discussions in the Tanzanian forest sector (e.g. Wily and Dewees, 2001; Lund and Treue, 2008; Blomley and Iddi, 2009; Blomley et al., 2010) in which many of the current REDD+ policy actors have a long history. The inputs by non-state actors required for 
effective and equitable policies were seen to span various types of expertise, as the below comment illustrates:

"I think it is high time we do away with the conservative way of thinking, being of what the government constitute. We should broaden consultation by taking on board people who can add value to the processes given the fact that REDD+ is multidisciplinary, it is a very wide ranging issue. They could involve people from the civil society, from the academia, from Zanzibar [...] You bring a professor of forestry, a professor of law, a representative of women's groups, a representative of the disabled, a representative of business community and so on and so forth. If that is done, I think REDD can develop well because people can inform, it can represent diverse views and expertise," (Domestic NGO technical advisor, April 21, 2011).

Finally, based on the conceptualization of community and family logics in the previous literature (Thornton et al., 2012), existing social ties within communities and households might be expected to positively shape distributive and procedural equity in REDD+. In our data, however, references to the social embeddedness of equity were presented mainly in the negative light. There was concern over inadequate attention to traditional gender roles in REDD+ planning and implementation and the subsequent risk that women would not be able to access the benefits, while bearing the consequences of forest use restrictions in their daily lives. Examples of unilateral decision making by village leaders and entering into contracts with project proponents without the consent of the broader community were given (cf. Mustalahti and Rakotonarivo, 2014). The concerns over the capture of REDD+ benefits by village elites at the cost of weaker actors, such as women, the poorest farmers and landless villagers engaging in 'illegal' activities such as charcoal making, were related in the arguments of the interviewees to a question which a national REDD+ benefit sharing mechanism as well as individual projects have to consider: whether benefits should be communal or distributed according to individual opportunity costs of REDD+. 


\section{Discussion and Conclusions}

The findings of our study suggest that the concept of equity may be related to highly heterogeneous institutional logics in the national REDD+ policy domain. They support our conceptual approach which proposes that the REDD+ domain represents an emerging international organizational field characterized by institutionalised meanings and practices, building on and overlapping with the more established fields of 'development' (Tvedt, 2006) and forest conservation and management. At least in the current readiness phase, the international flow of money in REDD+ is part of the development aid enterprise. The logics of international standards and buzzwords in REDD+ are very similar to those which may be found in the dynamics of international development and previous efforts of forest conservation, with their changing standards and discourses that are adopted and used in different ways when confronted with local realities. In particular, governments that aspire to be part of a certain international community, such as the 'REDD+ countries', may be susceptible to normative discourses employed by international organizations and adopt similar language and standards out of legitimacy and reputational concerns (Bernstein and Cashore, 2007; Happaerts, 2012). In a context where previous government policies to enhance social equity are perceived to have fallen short of their promises, the operationalization of such standards is likely to be met with particular caution and scrutiny by non-state actors.

Two logics emerged as particularly salient among the Tanzanian REDD+ actors: the market logic, addressing primarily the distributive dimension of equity, and the logic of participatory governance, mostly concerned with procedural equity.

It is perhaps unsurprising that the market logic appears so pervasive. After all, REDD+ is essentially based on the idea of putting the right price on the saved carbon and thus offering a sufficient incentive to change the behaviour and activities driving deforestation and forest degradation. Lack of incentives was widely cited as the main reason why previous forest conservation efforts had failed, suggesting that market approaches were perhaps seen as 'the thing to try next', again reflecting global trends and discourses. Delimiting the study to concern only policy actors, i.e. those actors participating in and having a voice - to varying degrees - in the national REDD+ policy 
process, may partly explain the relative scarcity of other types of arguments that might represent more 'endogenous' views on equity in the current context. Most of those policy actors, at least in 2011, were national level organizations with a specific environmental mandate. Other concerns may override those of environmental effectiveness at the local (sub-national) level.

Nevertheless, it is striking that the market logic as relating to such elementary resources for rural livelihoods as land and forest was not really questioned by the national REDD+ policy actors. There is mounting empirical evidence from Tanzania and elsewhere of the challenges of compensating lost access to natural resources with money (Cernea and Mathur, 2008; Rantala et al., 2013). In fact, the literature on development-related displacement has highlighted the associated risks since the 1970s (Cernea and Guggenheim, 1993; Cernea, 2003). The poorest and most vulnerable groups may be at a disadvantage when handling cash and "quickly left both cashless and assetless" (Cernea, 2003; p. 41). Furthermore, it may be difficult or even impossible to replace the knowledge, skills and identities related to particular resources, which also importantly condition people's resilience, with money (Cernea, 2003; Rantala et al., 2013). Therefore, considering equity in REDD+ to be merely a question of the right amount of compensation reaching the right people is potentially problematic.

The salience of the logic of participatory governance, which emphasizes multiple ways of public participation, hearing different voices and engaging with different perspectives, suggests widespread concern over procedural equity in REDD+ among the interviewed policy actors. What we have labelled 'participatory governance' could also be described as multilevel, polycentric or network governance (McGinnis, 1999; Forsyth, 2009) or "a negotiated order rather than an order defined by formalized legal frameworks" (Peters and Pierre, 2004; p. 71). Often discussed in relation to a transition from government to governance, the participatory logic could be expected to challenge not only the clientelistic logic of existing bureaucracy, but also the logic of modern bureaucracy. While stressing transparency, objectivity and rules as characteristics of a Weberian ideal type, the modern bureaucracy logic still represents a closed national bureaucratic system that according to some actors fails to address the demands of a 
dynamic, multi-scale REDD+ world. The interviewed government actors, however, clearly did not perceive the logic of participatory governance as incompatible with their rather positive idea of state administration. This may be related to the prominent role of participatory forest management in the formal forest policy and discourse in Tanzania during the past decades. Perhaps they conceive different roles reserved for modern bureaucracy and participatory governance; the latter playing a role in REDD+ planning and decision making, whereas equity in implementation and outcomes is seen as best guaranteed by the state.

In the global REDD+ policy debates, there are calls to develop social safeguards to monitor not only the carbon outcomes but also the delivery of broader co-benefits in the national REDD+ initiatives (UNFCCC, 2011; 2013) as well as to define the safeguards more precisely and make their monitoring binding (The REDD+ Safeguards Working Group et al., 2014). Observations on how the distinct equity logics are rooted in the national policy contexts and continuum highlight the need to go beyond broad international principles and standards in these processes, and instead stimulate detailed discussions on how concepts such as equity might really be operationalized in REDD+ initiatives in varying contexts. Such debates could reveal the often unidentified and unspoken underlying logics that guide the practices and preferences of distinct actors, and the assumptions and risks associated with those preferences. The enhanced deliberation, in turn, might increase the chances that participatory modes of governance result in more legitimate, and perhaps equitable and effective, REDD+ regimes according to the expectations of the policy actors.

\section{References}

Agrawal A, Nelson F, Adams WM, Sandbrook C. 2010. Governance and REDD: a reply to Wunder. Oryx 44: 337-338.

Angelsen A (ed). 2008. Moving ahead with REDD: Issues, Options and Implications.

Center for International Forestry Research: Bogor, Indonesia. 
Angelsen A, Brockhaus M, Kanninen M, Sills E, Sunderlin WD, Wertz-Kanounnikoff S (eds). 2009. Realising REDD+: National Strategy and Policy Options. Center for International Forestry Research: Bogor, Indonesia.

Angelsen A, Wertz-Kanounnikoff S. 2008. What are the key design issues for REDD and the criteria for assessing options? In Moving ahead with REDD: Issues, Options and Implications, Angelsen A (ed). Center for International Forestry Research: Bogor, Indonesia, pp11-21.

Balderas Torres A, Skutsch M. 2012. Splitting the difference: a proposal for benefit sharing in reduced emissions from deforestation and forest degradation (REDD+). Forests 3(1): 137-154.

Battilana J, Dorado S. 2010. Building sustainable hybrid organizations: the case of commercial microfinance organizations. Academy of Management Journal 53(6): 1419-1440. doi: 10.5465/AMJ.2010.57318391

Bernstein S, Cashore B. 2007. Can non $\square$ state global governance be legitimate? An analytical framework. Regulation and Governance 1(4): 347-371. doi:10.1111/j.1748-5991.2007.00021.x

Blomley T, Iddi S. 2009. Participatory Forest Management in Tanzania 1993 -2009. Lessons Learned and Experiences to Date. Forestry and Beekeeping Division, Ministry of Natural Resources and Tourism: Dar es Salaam, Tanzania. http://www.tzonline.org/pdf/participatoryforestmanagement2009.pdf [10 June 2014]

Blomley T, Ramadhani H, Mkwizu Y, Böhringer B. 2010. Hidden harvest: unlocking the economic potential of Community-Based Forest Management in Tanzania. In Governing Africa's Forests in a Globalized World, German LA, Karsenty A, Tiani AM (eds). Earthscan: London and Sterling, VA, pp126-143.

Brown K, Corbera E. 2003. Exploring equity and sustainable development in the new carbon economy. Climate Policy 3, Supplement 1, S41-S56. doi:10.1016/j.clipol.2003.10.004

Carter, C., Clegg, S., Wåhlin, N. 2011. When science meets strategic realpolitik: the case of the Copenhagen UN climate change summit. Critical Perspectives on Accounting 22: 682-697. 
Cernea MM. 2003. For a new economics of resettlement: a sociological critique of the compensation principle. International Social Science Journal 55: 37-45.

Cernea MM, Guggenheim SE (eds). 1993. Anthropological Approaches to Resettlement: Policy, Practice, and Theory. Westview Press: Boulder, CO. Cernea MM, Mathur HM (eds). 2008. Can Compensation Prevent Impoverishment? Reforming Resettlement through Investments. Oxford University Press: New Delhi.

Cotula L, Mayers J. 2009. Tenure in REDD - Start-point or Afterthought? Natural Resource Issues No. 15. International Institute for Environment and Development: London. http://pubs.iied.org/13554IIED.html [8 October 2013]

Daily News, April 10th 2013. Dar to Establish Carbon Monitoring Centre. Daily News: Dodoma, Tanzania.

Di Gregorio M, Brockhaus M, Cronin T, Muharrom E, Santoso L, Mardiah S, Büdenbender M. 2013. Equity and REDD+ in the media: a comparative analysis of policy discourses. Ecology and Society 18(2): 39.

DiMaggio PJ, Powell W. 1983. The iron cage revisited: institutional isomorphism and collective rationality in organizational fields. American Sociological Review 48: 147-60.

Forsyth T. 2009. Multilevel, multiactor governance in REDD+: participation, integration and coordination. In Realising REDD+: National Strategy and Policy Options, Angelsen A, Brockhaus M, Kanninen M, Sills E, Sunderlin WD, WertzKanounnikoff S (eds). Center for International Forestry Research (CIFOR): Bogor, Indonesia, pp113-122.

Friedland R, Alford R. 1991. Bringing society back in: symbols, practices and institutional contradictions. In The New Institutionalism in Organizational Analysis, Powell WW, Maggio PJ (eds). University of Chicago Press: Chicago, pp232-263.

Geertz, C. 1973. Thick description: toward an interpretive theory of culture. In The Interpretation of Cultures: Selected Essays, Geertz, C. Basic Books: New York, pp13-30. 
Greenwood R, Díaz AM, Li SX, Lorente JC. 2010. The multiplicity of institutional logics and the heterogeneity of organizational responses. Organization Science 21(2): 521-539.

Greenwood R, Raynard M, Kodih F, Micelotta ER, Lounsbury M. 2011. Institutional Complexity and Organizational Responses. The Academy of Management Annals 5(1): 317-371.

Griffiths T. 2008. Seeing 'REDD'? Forests, climate change mitigation and the rights of indigenous peoples and local communities. Forest Peoples Programme (FPP): Moreton-in-Marsh, UK.

Happaerts S. 2012. Are you talking to us? How subnational governments respond to global sustainable development governance. Environmental Policy and Governance 22(2): 127-142. doi:10.1002/eet.1577

Heyward M. 2007. Equity and international climate change negotiations: a matter of perspective. Climate Policy 7: 518-534.

Kanowski PJ, McDermott CL, Cashore, BW. 2011. Implementing REDD+: lessons from analysis of forest governance. Environmental Science and Policy 14: 111-117.

Kraatz MS, Block ES. 2008. Organizational implications of institutional pluralism. In The Sage Handbook of Organizational Institutionalism, Greenwood R, Oliver C, Sahlin-Andersson K, Subbady R. (eds). Sage: London, pp 243-275.

Larson AM, Barry D, Dahal GR, Colfer CJP. (eds). 2010. Forests for People: Community Rights and Forest Tenure Reform. Earthscan: London.

Laumann EO, Marsden PV, Prensky D. 1992. The boundary specification problem in network analysis. In Research Methods in Social Network Analysis, Freeman LC, White DR, Romney AK. (eds). Transaction Publishers: New Brunswick, pp61709.

Lund JF, Treue T. 2008. Are we getting there? Evidence of decentralized forest management from the Tanzanian Miombo woodlands. World Development 36(12): 2780-2800.

Luttrell C, Loft L, Gebara MF, Kweka D, Brockhaus M, Angelsen A, Sunderlin WD. 2013. Who should benefit from REDD+? Rationales and realities. Ecology and Society 18(4): 52 . 
McDermott M, Mahanty S, Schreckenberg K. 2011. Examining equity: a multidimensional framework for assessing equity in payments for ecosystem services. Environmental Science and Policy. doi:10.1016/j.envsci.2012.10.006 McGinnis MD (ed). 1999. Polycentric Governance and Development: Readings from the Workshop in Political Theory and Policy Analysis. University of Michigan Press.

Meyer JW, Rowan B. 1977. Institutional organizations: formal structure as myth and ceremony. American Journal of Sociology 83: 340-63.

Mitchell, C. 2000. Case and situation analysis. In Case Study Method, Romm R, Foster $P$ (eds.). London: Sage, pp 234-258.

Mustalahti I, Bolin A, Boyd E, Paavola J. 2012. Can REDD+ reconcile local priorities and needs with global mitigation benefits? Lessons from Angai forest, Tanzania. Ecology and Society 17(1): 16.

Mustalahti I, Rakotonarivo OS. 2014. REDD+ and Empowered Deliberative Democracy: learning from Tanzania. World Development 59: 199-211.

Paavola J. 2007. Institutions and environmental governance: a reconceptualization. Ecological Economics 63(1): 93-103. doi:10.1016/j.ecolecon.2006.09.026

Peskett L, Vickers B, Graham K. 2011. Equity Issues in REDD. Working Paper produced for the project "Safeguarding Local Equity as Global Values of Ecosystem Services Rise". Overseas Development Institute. http://www.theredddesk.org/resources/reports/equity_issues_in_redd [9 October 2013]

Peters BG, Pierre J. 2004. Multi-level governance and democracy: a Faustian bargain? In Multi-level Governance, Bache I, Flinders M (eds). Oxford University Press: Oxford, pp75-89.

Pham TT, Brockhaus M, Wong G, Le ND, Tjajadi JS, Loft L, Luttrell C, Assembe Mvondo S. 2013. Approaches to Benefit Sharing: A Preliminary Comparative Analysis of 13 REDD + Countries. Center for International Forestry Research: Bogor, Indonesia.

Phelps J, Webb EL, Agrawal A. 2010. Does REDD+ threaten to recentralize forest governance? Science 328: 312-313. 
Rantala S, Bullock R, Mbegu MA, German LA. 2012. Community-Based Forest Management: what scope for conservation and livelihood co-benefits? Experience from the East Usambara Mountains, Tanzania. Journal of Sustainable Forestry 31(8): 777-797.

Rantala S, Vihemäki H, Swallow BM, Jambiya G. 2013. Who gains and who loses from compensated displacement from protected areas? The case of the Derema Corridor. Conservation and Society 11(2): 97-111.

Rantala S, Di Gregorio M. (in press). Multistakeholder environmental governance in action: REDD+ discourse coalitions in Tanzania. Ecology \& Society.

Reay T, Hinings, CR. 2009. Managing the rivalry of competing institutional logics. Organization Studies 30(06): 629-652. doi: 10.1177/0170840609104803

The REDD+ Safeguards Working Group, The Accra Caucus, members of the Indigenous Peoples' Caucus. 2014. Submission by The REDD+ Safeguards Working Group, The Accra Caucus and members of the Indigenous Peoples' Caucus on the methodological issues related to non-carbon benefits resulting from the implementation of REDD+ activities. http://unfccc.int/resource/docs/2014/smsn/ngo/409.pdf [4 June 2014]

Ribot, J, Larson, A. 2012. Reducing REDD risks: affirmative policy on an uneven playing field. International Journal of the Commons 6(2): 233-254.

Ryan GW, Bernard HR. 2003. Techniques to identify themes. Field Methods 15(1): 85109. doi:10.1177/1525822X02239569

Sandbrook C, Nelson F, Adams WM. 2010. Carbon, forests and the REDD paradox. Oryx 44: 330-334.

Schroeder R, Martin KS, Wilson B, Sen D. 2008. Third World environmental justice. Society and Natural Resources 21(7): 547-555. doi:10.1080/08941920802100721

Skutsch M, Simon C, Velazquez A, Fernández JC. 2013. Rights to carbon and payments for services rendered under REDD+: options for the case of Mexico. Global Environmental Change 23(4): 813-825. doi:10.1016/j.gloenvcha.2013.02.015 
Tanzania Forest Conservation Group (TFCG), MJUMITA. 2011. A one-step guide to making the National REDD strategy more pro-poor. Tanzania Forest Conservation Group: Dar es Salaam, Tanzania. http://www.tfcg.org/pdf/MJUMITA\%20and\%20TFCG\%20Policy\%20Brief\%20on\% 20Land\%20Issues\%20and\%20REDD.pdf [10 June 2014]

Thompson MC, Baruah M, Carr ER. 2011. Seeing REDD+ as a project of environmental governance. Environmental Science and Policy 14: 100-110.

Thornton PH. 2004. Markets from Culture: Institutional Logics and Organizational Decisions in Higher Education Publishing. Stanford: Stanford University Press.

Thornton PH, Ocasio W. 1999. Institutional logics and the historical contingency of power in organizations: executive succession in the higher education publishing industry 1958-1990. American Journal of Sociology 105(3): 801-843.

Thornton PH, Ocasio W. 2008. Institutional logics. In The Sage Handbook of Organizational Institutionalism, Greenwood R, Oliver C, Sahlin-Andersson K, Subbady R. (eds). Sage: London, pp 99-129.

Thornton PH, Ocasio W, Lounsbury M. 2012. The Institutional Logics Perspective. A New Approach to Culture, Structure and Process. Oxford: Oxford University Press.

Tvedt T. 2006. The international aid system and the non-governmental organisations: a new research agenda. Journal of International Development 18(5): 677-690.

United Nations Framework Convention on Climate Change (UNFCCC). 2011. Report of the Conference of the Parties on its Sixteenth Session, Held in Cancun from 29 November to 10 December 2010 (FCCC/CP/2010/7/Add.1). Cancun, Mexico. http://unfccc.int/resource/docs/2010/cop16/eng/07a01.pdf [8 October 2013]

United Nations Framework Convention on Climate Change (UNFCCC). 2013. The timing and the frequency of presentations of the summary of information on how all the safeguards referred to in decision 1/CP.16, appendix I, are being addressed and respected (Decision -/CP.19). Warsaw, Poland. http://www.reddmonitor.org/wordpress/wpcontent/uploads/2013/11/cop19_safeguards_1cp16a1.pdf [4 June 2014] 
United Republic of Tanzania (URT). 2010. The First Draft National Strategy for Reduced Emissions from Deforestation and Forest Degradation (REDD+). Dar es Salaam, Tanzania.

United Republic of Tanzania (URT). 2013. National Strategy for Reduced Emissions from Deforestation and Forest Degradation (REDD+). Dar es Salaam, Tanzania. Vyamana VG. 2009. Participatory forest management in the Eastern Arc Mountains of Tanzania: who benefits? International Forestry Review 11(2): 239-253.

Weber M. 1964. [orig. 1947] The Theory of Social and Economic Organization. Translated by A.M. Henderson and Talcott Parsons. New York: The Free Press. Wiegandt E. 2001. Climate change, equity and international negotiations. In International Relations and Global Climate Change, Luterbacher U, Sprinz DF (eds). MIT Press: Cambridge, MA, pp127-150.

Wily LA, Dewees PA. 2001. From Users to Custodians: Changing Relations Between People and the State in Forest Management in Tanzania. World Bank Policy Research Working Paper 2569. World Bank: Washington, DC.

Wutich A, Brewis A, York AM, Stotts R. 2013. Rules, norms, and injustice: a crosscultural study of perceptions of justice in water institutions. Society and Natural Resources 26(7): 795-809. doi:10.1080/08941920.2012.723302

Yu K-H. 2013. Institutionalization in the context of institutional pluralism: politics as a generative process. Organization Studies 34(1): 105-131. 


\section{Table 1. Distribution of organizational actors in the interview data on REDD+ institutional logics.}

\begin{tabular}{ll}
\hline Organizational type & $\mathbf{n}$ \\
\hline Domestic NGO & 8 \\
\hline Government ministry or executive department & 7 \\
\hline International NGO & 4 \\
\hline Foreign government agency (embassy) & 3 \\
\hline Intergovernmental organization & 3 \\
\hline Academic (national university) & 1 \\
\hline Domestic business & 1 \\
\hline International business & 1 \\
\hline & Total \\
\hline
\end{tabular}


Table 2. REDD+ equity institutional logics identified based on the arguments of interviewed policy actors.

\begin{tabular}{|c|c|c|c|c|}
\hline Logic & $\begin{array}{l}\text { Inner tension / } \\
\text { Distinction } \\
\text { within }\end{array}$ & Rationale & $\begin{array}{l}\text { Central } \\
\text { vocabulary I } \\
\text { arguments }\end{array}$ & $\begin{array}{l}\text { Representing } \\
\text { (types of } \\
\text { organizations) }\end{array}$ \\
\hline Market & - & $\begin{array}{l}\text { WHY equity: Benefits/rewards should go } \\
\text { to those whose behaviour needs to } \\
\text { change in order to achieve effective } \\
\text { REDD+ and who incur costs from } \\
\text { REDD+. Enhancing local participation } \\
\text { may also lower transaction costs and } \\
\text { increase the cost-efficiency of REDD+. }\end{array}$ & $\begin{array}{l}\text { Incentives, benefits, } \\
\text { benefit sharing, } \\
\text { costs, alternative } \\
\text { income }\end{array}$ & All types \\
\hline \multirow[t]{2}{*}{ Rights } & Legal & $\begin{array}{l}\text { WHY equity: benefits belong to those } \\
\text { holding legal rights to forests and land. }\end{array}$ & $\begin{array}{l}\text { Ownership, tenure, } \\
\text { property rights }\end{array}$ & $\begin{array}{l}\text { Government, } \\
\text { domestic NGO }\end{array}$ \\
\hline & Moral & $\begin{array}{l}\text { WHY equity: it is appropriate to involve } \\
\text { and share benefits with those whose } \\
\text { livelihoods are affected by REDD+, } \\
\text { regardless of their legal position. }\end{array}$ & $\begin{array}{l}\text { Rights, } \\
\text { marginalization, } \\
\text { eviction }\end{array}$ & $\begin{array}{l}\text { Domestic NGO, } \\
\text { academic }\end{array}$ \\
\hline $\begin{array}{l}\text { State } \\
\text { bureaucracy }\end{array}$ & Modern & $\begin{array}{l}\text { HOW equity: equity will result from an } \\
\text { efficient state bureaucratic system } \\
\text { administering REDD+ accounting and } \\
\text { payments. }\end{array}$ & $\begin{array}{l}\text { Transparency, } \\
\text { accountability, good } \\
\text { governance }\end{array}$ & $\begin{array}{l}\text { Government, } \\
\text { academic }\end{array}$ \\
\hline
\end{tabular}




\begin{tabular}{|c|c|c|c|c|}
\hline & Existing & $\begin{array}{l}\text { WHAT hampers equity: equity is } \\
\text { undermined by existing power } \\
\text { structures; decision making and benefits } \\
\text { are concentrated in the central } \\
\text { government. }\end{array}$ & $\begin{array}{l}\text { Precedent/ } \\
\text { history/experience } \\
\text { of unequal benefit } \\
\text { sharing, weak } \\
\text { government, } \\
\text { corruption }\end{array}$ & $\begin{array}{l}\text { Domestic NGO, } \\
\text { domestic business, } \\
\text { academic, } \\
\text { international NGO, } \\
\text { foreign government }\end{array}$ \\
\hline \multirow[t]{2}{*}{ Standards } & $\begin{array}{l}\text { Established } \\
\text { standards }\end{array}$ & $\begin{array}{l}\text { WHY and HOW equity: equity follows } \\
\text { from international standards, } \\
\text { agreements and collaboration, properly } \\
\text { implemented at national and local levels. }\end{array}$ & $\begin{array}{l}\text { Goal, mission, } \\
\text { strategy, action } \\
\text { plan }\end{array}$ & $\begin{array}{l}\text { Government, } \\
\text { domestic NGO, } \\
\text { intergovernmental }\end{array}$ \\
\hline & Buzzwords & $\begin{array}{l}\text { WHY equity: equity discourse is a } \\
\text { superficial reflection of imposed } \\
\text { standards for approval and legitimacy, } \\
\text { not properly implemented. }\end{array}$ & $\begin{array}{l}\text { Lipservice, "making } \\
\text { the right noises", } \\
\text { non- } \\
\text { implementation, } \\
\text { business as usual }\end{array}$ & $\begin{array}{l}\text { Domestic NGO, } \\
\text { domestic business, } \\
\text { international NGO, } \\
\text { intergovernmental }\end{array}$ \\
\hline $\begin{array}{l}\text { Participatory } \\
\text { governance }\end{array}$ & - & $\begin{array}{l}\text { WHY and HOW equity: stakeholder } \\
\text { participation across scales guarantees } \\
\text { effectiveness and equity, because the } \\
\text { state needs wide support for successful } \\
\text { policies. Equity of outcomes is } \\
\text { enhanced if different perspectives are } \\
\text { represented. }\end{array}$ & $\begin{array}{l}\text { Participation, } \\
\text { inclusion, } \\
\text { involvement, } \\
\text { engagement, } \\
\text { stakeholders, } \\
\text { representation, } \\
\text { multidisciplinary, } \\
\text { local knowledge }\end{array}$ & All types \\
\hline
\end{tabular}




\begin{tabular}{lllll}
\hline $\begin{array}{l}\text { Social } \\
\text { embeddedness }\end{array}$ & Community & $\begin{array}{l}\text { WHAT hampers equity: equity outcomes } \\
\text { are shaped by unbalanced power } \\
\text { relations and practices of the } \\
\text { community. }\end{array}$ & $\begin{array}{l}\text { Elite capture, "weak } \\
\text { voices", } \\
\text { vulnerability }\end{array}$ & $\begin{array}{l}\text { Domestic NGO, } \\
\text { academic, foreign } \\
\text { government }\end{array}$ \\
\cline { 2 - 5 } & Family I & WHAT hampers equity: equity is not & Gender, culture, \\
household & $\begin{array}{l}\text { realized within households due to } \\
\text { gendered positions and division of } \\
\text { labour. }\end{array}$ & & $\begin{array}{l}\text { Government, } \\
\text { international NGO } \\
\text { (esp. Zanzibar) }\end{array}$ \\
& & &
\end{tabular}


